\title{
IDP and Refugee Return to Northern Iraq: Sustainable Returns or Demographic Bombs?
}

\author{
David Romano
}

\section{Abstract}

Regime change in Iraq has opened the door to the return of hundreds of thousands of refugees and internally displaced persons (IDPs), the majority of whom were expelled from Kirkuk and other areas in northern Iraq. The Iraqi case presents three broad, readily identifiable categories of displaced persons: refugees in Iraq's neighbouring states, internally displaced persons, and refugees and migrants in third countries further afield. The first two categories include the largest numbers of displaced people as well as the majority of those with a great desire or pressing need to return to their homelands in Iraq. Although some of those displaced have succeeded in making a good life for themselves in their new new homes, those who did not manage well after their displacement generally long to return to their original towns and homes. However, the following general problems, in order of gravity, impede the success and sustainability of returns to northern Iraq: (i) sectarian competition over political structures and power distributions in post-Saddam Iraq; (ii) increasing lack of security in Iraq; (iii) insufficient preparations and slow policy implementation by the former CPA and Coalition Forces; (iv) insufficient financial resources to deal with the full magnitude of the displacement problem in Iraq; and $(v)$ high expectations of returnees vis-a-vis continuing lack of opportunities and the slow rate of positive developments in the social, economic and political situation in Iraq. However, the emerging political contests over the future of the new Iraq greatly complicate effective and comprehensive return programs; the ultimate test of success and sustainability of return to Iraq will depend on the future of post-Saddam Iraq itself.

\section{Résumé}

Le changement de régime en Irak a ouvert la porte au retour de centaines de milliers de réfugiés et de personnes déplacées à l'intérieur de leur propre pays (PDIP), dont la majorité avaient été expulsés de Kirkuk et d'autres régions dans le nord de l'Irak.

Le cas irakien présente trois grandes catégories de personnes déplacées facilement identifiables: les réfugiés vivant dans les états voisins de l'Irak, les personnes déplacées à l'intérieur, et les réfugiés et migrants se trouvant dans des pays tiers plus éloignés. Les deux premières catégories englobent le plus grand nombre de personnes déplacées, aussi bien que la majorité de ceux ayant un grand désir ou un besoin impérieux de retourner dans leurs territoires d'origine en Irak.

Bien que certains des déplacés aient réussi à refaire leur vie de façon satisfaisante dans leurs nouveaux terres d'accueil, ceux qui ne se sont pas bien tirés d'affaire après leur déplacement éprouvent généralement le désir de retourner dans leurs villes et leurs foyers d'origines. Cependant, les problèmes généraux suivants, pris en ordre d'importance, entravent la réussite et la viabilité à long terme d'un retour vers le nord de l'Irak: (i) les rivalités sectaires pour le contrôle des structures politiques et la répartition du pouvoir dans l'Irak post-Saddam; (ii) le manque croissant de sécurité en Irak; (iii) les préparatifs insuffisants et la lenteur dans l'implémentation des politiques par l'ex APC (Autorité Provisoire de la Coalition) et les Forces de la coalition; (iv) des ressources financières insuffisantes pour traiter le problème de déplacement en Irak dans toute son ampleur; et (v) les attentes élevées des réfugiés par rapport au manque incessant d'opportunités et à la lenteur de développements positifs quant à la situation sociale, économique et politique en Irak. Cependant, les rivalités politiques émergeantes pour décider de l'avenir du nouvel Irak compliquent énormément les programmes de retour efficaces et globaux; le test ultime de la réussite et de la viabilité à long 
terme du retour en Irak dépendra en fin de compte du sort même de l'Irak post-Saddam.

\section{Introduction}

$\mathrm{R}$ egime change in Iraq has opened the door to the return of hundreds of thousands of refugees and internally displaced persons (IDPs), the majority of whom were expelled from Kirkuk and other areas in northern Iraq. The international community, the (potential) returnees, and most political parties in Iraq all support the principle of return of people forcibly displaced by Saddam's regime. Continuing uncertainty regarding Iraq's future poses serious problems, however: although a post-war country since May of 2003, Iraq can not yet accurately be described as in a post-conflict situation. The sustainability of returns very much depends on how incipient sectarian competition for power in the new Iraq plays out, especially since IDPs and refugees have emerged as one of the weapons available in the emerging contest. In trying to address the return issue in an extremely fair, legal, and regulated manner, Coalition Forces have also succumbed to near paralysis regarding the problem, exacerbating the risk of civil conflict centred around returning IDPs and refugees in northern Iraq. The oil-rich, multi-ethnic, strategic and contested region of Kirkuk in particular may be the lynchpin for either "getting it right" in Iraq, or igniting a civil conflict that not only makes returns unsustainable, but also creates large numbers of new displaced people.

\section{Potential Returnees to Iraq}

Although reliable estimates remain difficult to obtain, prior to the 2003 war Iraq had roughly 800,000 refugees residing in neighbouring countries-Iran (202,000 registered by the UNHCR), Jordan (around 300,000, mostly unregistered), Saudi Arabia (5,100 in the Rafha camp near the Iraqi border), and Syria (40,000, unregistered). ${ }^{1}$ These refugees came from failed Kurdish uprisings in the 1960s, 1975, 1980s, and 1991, ethnic cleansing campaigns undertaken against Kurdish, Turkomen, and Christian villages in the north since the 1960s, the failed Shiite uprising of 1991, the draining of the southern marshlands in the early 1990s, Iraq's expulsion of so-called "Persians" in 1974 (hundreds of thousands of Iraqis listed as Persian subjects in the Ottoman-era archives), and individual cases of persecution committed by a paranoid, brutal regime. Many of the Iraqi refugees who remained in neighbouring countries for many years lived in poverty and never successfully integrated into their host countries. In Saudi Arabia in particular, refugees from the 1991 Gulf War were still in bleak, desolate camps by the time of the 2003 Iraq war.
In 2003, some 800,000 internally displaced persons also resided in Iraqi Kurdistan's Autonomous Zone, mostly victims of the Arabization ethnic cleansing campaigns conducted since the 1960s (100,000 were expelled from mostly the Kirkuk region as recently as the 1990s). A further estimated 100,000 IDPs could be found in central Iraq, most of whom had been either internally exiled from the north by Saddam's regime or pushed out of the Kurdistan Autonomous Zone by the new Kurdish authorities there (typically due to past allegiance with Saddam's regime, but also sometimes because of tribal rivalries or other reasons). ${ }^{2}$ Some 100,000 to 300,000 IDPs also existed on meagre means in southern Iraq, mostly victims of the suppression of the 1991 uprising there, a counter-insurgency campaign that included draining the marshlands of southern Iraq and thereby destroying the ecosystem on which the Shiite Marsh Arab population depended.

In addition to these groups of refugees and IDPs, hundreds of thousands of Iraqis received asylum in third countries (mostly Europe, the United States, Canada, and Australia) or migrated there through underground peoplesmuggling networks. Many of these included educated, trained professionals whose departure from Iraq represented a significant "brain drain" for the country. Although "economic migrants" from Iraq may not technically fit into the category of forced displacement, they are in practice difficult to distinguish from displaced persons because of the multiplicity of factors that led to their departure from their homeland and a paucity of reliable data about them.

All told, there may be up to three million Iraqi exiles abroad, 500,000 of whom may ask the UNHCR for assistance to return home. ${ }^{3}$

Hence the Iraqi case presents three broad, readily identifiable categories of displaced persons: refugees in Iraq's neighbouring states, internally displaced persons, and refugees and migrants in third countries further afield. The first two categories include the largest numbers of displaced people as well as the majority of those with a great desire or pressing need to return to their homelands in Iraq. Although some refugees succeeded in making a good life for themselves in places such as Tehran or Amman, very large numbers continue to exist on the margins of the economic and social spheres of their host countries. The same holds true for Iraqi IDPs-while many individuals and families successfully found careers and new homes in places such as Erbil, Suleimaniya, Duhok, and Zakho (the major towns of Iraqi Kurdistan), those who did not manage well after their displacement generally long to return to their original towns and homes. Of those Iraqis who moved on to third countries such as Germany or Britain, fewer are likely to express an immediate desire or pressing need to resettle to 
Iraq, although some have already returned (those whom the author met in Iraq in 2003-2004 all explained their decision to return in ideological terms - the wish to rebuild and participate in the renewal of their homeland).

\section{Positive Factors Influencing the Return Process in Northern Iraq}

Saddam Hussein's Ba'athist regime, and to a lesser extent previous Arab nationalist authoritarian governments in Baghdad, were responsible for the overwhelming majority of displacement in Iraq. With the toppling of the regime, the door opened for the return of the more than 1.5 million people who lost their homes and lands. Especially Iraqi Kurds and Shiites expressed heartfelt joy at the ousting of Saddam's government, since they formed the disproportionate majority of those he targeted and displaced over the years. Many displaced persons now look forward to reclaiming their original homes or at least moving back to their old neighbourhoods, as well as receiving compensation for what they had taken from them.

The United States also foresaw many of the difficulties and complexities involved with effecting returns especially in northern Iraq, and thus almost a year before the war the U.S. State Department formed DART teams (Disaster Assistance Response Team) to begin planning on such issues. ${ }^{4}$ The teams prepared studies on various humanitarian and post-war problems that would likely arise in Iraq, including complications regarding refugee and IDP returns. The presence of some 200,000 Arab settlers in Kirkuk and its surrounding areas, brought in from southern Iraq by Saddam's government during the Arabization programs, stood out as one of the major issues that would have to be addressed. The United States adopted a policy determined to effect returns in a legal, fair, neutral way that does not violate the Guiding Principles on International Displacement. Specifically, they stressed that there should be (1) no new forced displacement, (2) protection of displaced populations, and (3) restitution or compensation for displaced persons determined in a uniform, legal manner.

During the war, the Americans also managed to secure a commitment from their Iraqi Kurdish allies to reign in returning Kurds, and prevent the forced displacement of ethnic Arabs from town just south of the Kurdish Autonomous Zone (towns such as Kirkuk, Mosul, Makhmour, and Khanequin). Although KDP (Kurdistan Democratic Party) and PUK (Patriotic Union of Kurdistan) forces ran ahead of their American allies and entered Mosul and Kirkuk before U.S. forces did, the Kurdish leadership generally honoured their commitment regarding no new forced displacement. Although a few isolated cases of intimidation and expulsions of Arabs occurred, and significant numbers of ethnic Arabs fled the advancing Kurdish and U.S. forces, the Kurdish leadership agreed to leave the return process, compensation issue, and reallocation of land to the legal, organized procedures envisioned by the Americans. ${ }^{5}$ In the summer of 2004, Human Rights Watch described the situation around Kirkuk in the following way:

Much of the Arab population brought to rural areas in the north during the Arabization campaign fled during the war, leaving large swaths of territory unpopulated. Among the reasons cited by the Arabs for their flight were the intensity of the bombing campaign and the proximity of the front lines with its associated dangers, fears of revenge from returning Kurds, and in many cases the remarkable recognition that the land they lived on did not truly belong to them, but rather to the Kurds or other minorities who had been expelled. Equally remarkable, although sporadic violence and intimidation by Peshmerga forces did take place (see below), Human Rights Watch is not aware of a single massacre committed against Arab settlers by returning Kurds or other minorities. This is an experience vastly different from that of the Balkans, where bloodshed was routine during the various "ethnic cleansing" campaigns that characterized those conflicts. ${ }^{6}$

Hence many returns could be accomplished without having to displace settlers, since many had fled during the war. Many of those who did not flee recognized that they were on someone else's land, and expressed a willingness to relocate if they could be provided with compensation and a place to relocate to. The Kurdish leadership agreed to the legal approach regarding returns with the understanding that returns and restitution would be effected soon, however.

Finally, some Iraqi Kurds who had settled in third countries in Europe or elsewhere also began returning after the 2003 war. Many of these were educated, prosperous professionals and business people who saw renewed hope for Iraq with the end of Saddam's regime. Many Kurdish Iraqis hoped that the war, and the prominent role played by the Kurdish parties in assisting the Coalition Forces, would lead to a renaissance or perhaps even independence for Iraqi Kurdistan. Their return in many ways represents an ideal scenario-renewed hope in their homeland made them voluntary returnees, and the skills, knowledge, foreign contacts, and investment funds they brought with them formed a much needed and generally welcome contribution to long isolated Iraqi communities. Some Iraqi Kurds interviewed by this author in 2003-2004 had sold homes and businesses in the United States and Europe in order to return with their families. In one case, a young University of Suleimaniya graduate, after finally managing to make it to Europe with the aid of a "people smuggler" (on his eighth attempt), 
decided to turn around and go back to Iraqi Kurdistan when Saddam's regime collapsed. He did so out of renewed hope for a positive future in his homeland. ${ }^{7}$

\section{Problems Impacting Returns to Northern Iraq and Their Sustainability}

The following general problems, in order of gravity, impede the success and sustainability of returns to northern Iraq:

1. sectarian competition over political structures and power distributions in post-Saddam Iraq,

2. increasing lack of security in Iraq,

3. insufficient preparations and slow policy implementation by the former CPA and Coalition Forces,

4. insufficient financial resources to deal with the full magnitude of the displacement problem in Iraq, and

5. high expectations of returnees vis-a-vis continuing lack of opportunities and the slow rate of positive developments in the social, economic and political situation in Iraq.

\section{Sectarian Competition over Political Structures and Power Distributions in Post-Saddam Iraq}

As anyone familiar with the Bosnian case could attest, effecting returns in multi-ethnic post-conflict contexts presents many problems. The most explosive sectarian division in Iraq since the founding of the state has been the divide between Kurdish and Arab nationalism. It was in order to deny Kurdish nationalist claims to the strategic oil fields of Kirkuk that Saddam's regime conducted ethnic cleansing campaigns beginning in the 1970s. His government also gerrymandered the Kirkuk area into a new governorate separate from the predominantly Kurdish governorates of Erbil and Suleimaniya, naming the new administrative region "Ta'amim" (nationalization).

With the fall of Saddam's regime, Iraqi Kurds are demanding restitution of past wrongs. Specifically, they insist on the reincorporation of Kirkuk into the administrative boundaries of Iraqi Kurdistan (a 1970 autonomy agreement between the Iraqi government and Kurdish rebels even broke down over the issue of Kirkuk's inclusion in the Kurdish Autonomous Zone), compensation for and the return of those displaced by Saddam's regime, and the departure of Arab settlers from the region. Of course, Saddam's implantation of some 200,000 mostly Shiite Arab settlers from southern Iraq during his Arabization campaigns greatly complicates the issue, as many of these settlers have been in the area for more than thirty years. Saddam's government induced them to move north with generous grants of seized property and, in most cases, a cash incentive of 10,000 dinar (around US\$35,000 until 1991).
Although they do differentiate between settlers and the indigenous Arabs of northern Iraq, those who were forcibly displaced disparagingly refer to the settlers as the " 10,000 Dinar Arabs." Many of those who fled during March and April of 2003 have become so-called "new case load IDPs," living in tents or abandoned buildings near Mosul. Others who already returned south no longer had homes in their former lands, and they too await assistance in makeshift camps pitched in the middle of the desert. Settlers who remain in Kirkuk (most of those in the urban part of Kirkuk, as opposed to outlying rural areas, remained) and other nearby parts of northern Iraq await compensation or the settling of conflicting land claims before moving. Also, many have intermarried with the indigenous Arabs, Turkmen, and Kurds of the area, producing children born in northern Iraq and only familiar with northern Iraq, but still seen by many as settlers from the south.

Many Arabs and Turkmen in Iraq fear that the Kurdish parties (mainly the KDP and PUK) are pushing hard for the return of displaced persons in order to take control of the oil-rich areas around the towns of Kirkuk, Mosul, Makhmour, Khanequin, and Kalar, however. With the oil resources of these areas under their direct control, the Iraqi Kurds might then have the economic basis from which they could separate from Iraq and declare an independent Kurdish state. Neighbouring Turkey also threatened to intervene militarily should Iraqi Kurds make a move to forcibly take control of Kirkuk and the surrounding oil fields. Sunni Arab insurgents in the country have told the settlers around Kirkuk to stay where they are, in the hope of maintaining Arab control of the area.

Kurds in turn fear that Arab and some Turkmen leaders therefore plan on blocking returns, and eventually reasserting authoritarian central government control over all of Iraqi Kurdistan. Kurds, Turkmen, and Christians displaced over the years also fear that if they do not return now, authorities in Baghdad will renege on promises to allow them and help them to return later. Hence Kurdish political leaders have encouraged the returns sooner rather than later, in an attempt to bolster Kurdish numbers in places such as Kirkuk ahead of elections and a possible census. ${ }^{8}$ U.S. army officials responsible for IDPs in Ta'amiim governorate (which includes Kirkuk) estimated in August 2003 that 63 per cent or IDPs in the area were Kurdish, 28 per cent Arab, 7 per cent Turkmen, and 2 per cent of mixed ethnicity (Appendix 1 contains a graph of this ethnic distribution).

Arabs, Kurds, and Turkmen also jockey for position in new municipal councils and other government institutions, positions that could help them affect the return process and the distribution of resources to their respective communi- 
ties. Between April 2003 and January 2005, simmering tension between the different sectarian communities broke out into violence on several occasions, with shootings at political demonstrations and the targeting of individuals because they were Kurdish, Arab or Turkmen. Although up until the beginning of 2007 sectarian strife in Iraq centred mostly around Baghdad, these multi-ethnic areas just south of the Kurdish Autonomous Zone (especially Kirkuk) also remain at risk for similar conflicts.

\section{Increasing Lack of Security in Iraq}

The continuing insurgency in Iraq impedes both the return of IDPs and especially refugees, and prevents both Coalition Authorities and international organizations from assisting in the process. Even assessing the numbers of returnees, their needs, and conflicting property claims has become a dangerous task. The United Nations (UNHCR and UNOPS, the United Nations Office for Project Services) originally held the designation of focal point for refugees and IDPs in the Kurdish Autonomous Zone, and the IOM (International Organization for Migration) was to act as the focal point south of the Kurdish area. After the August 19, 2003, bombing of the U.N. headquarters in Baghdad, however, the U.N. and many other international organizations withdrew their international staff from Iraq. The IOM functions in the country with local staff, while its international experts assigned to Iraq operate from Amman. Hence the expertise and resources that could be used to put in place a sustainable, comprehensive return process remain largely dormant. As a result, "UNHCR does not promote return to Iraq, but only facilitates the voluntary repatriation of those refugees who insist on going back." " UNHCR policy likewise asks all states to forego any forced returns to Iraq:

9. Against the aforementioned backdrop, UNHCR therefore maintains its advice as follows:

- UNHCR strongly advises States to suspend the forced returns of Iraqi nationals to all parts of Iraq until further notice.

- UNHCR asks States to postpone the introduction of measures which are intended to induce voluntary returns, including of rejected cases. This includes financial or other incentives and particularly deterrent or punitive measures.

- UNHCR further reiterates its request that, within the framework of international solidarity and burden-sharing, asylum-seekers from Iraq should not be returned to other countries in the region, regardless of their prior stay in or transit through these countries. ${ }^{10}$
Until the security situation improves, returnees therefore remain very unlikely to receive much international support once they are in Iraq. Returns are also likely to prove temporary if the security situation does not improve soon. Likewise, no return program can be considered successful if the returnees find themselves physically threatened.

Finally, lack of security produces additional IDPs in northern Iraq, as Kurds living in Baghdad and other central parts of the country face intimidation by Arab Sunni insurgents and flee northwards. ${ }^{11}$ Insurgents and criminal kidnapping gangs have also increasingly targeted the Iraqi Christian community in central and southern Iraq, leading many to flee to Iraqi Kurdistan, Syria, or other destinations outside the country. Although numbers remain very difficult to ascertain since aid organizations do not track migrants according to religion, estimates in the fall of 2004 typically fell between 30,000 and 40,000 Christians fearing for their own safety and consequently displaced. ${ }^{12}$ Saddam's regime displaced many Christians from northern Iraq at the same time that ethnic Kurds and Turkmen were targeted, so those Christians heading to safer areas in Iraqi Kurdistan today are for the most part originally from that area in any case. Kurdish authorities told this author on various occasions that they welcome the return of Christians displaced by Saddam, although it remains to be seen how successfully these communities will be reconstituted. In the Kirkuk area alone, at least seventeen Christian villages were destroyed in what one former villager (now residing in Baghdad) described as "Saddam's Islamicization campaign of the 1970s."13

\section{Insufficient Preparations and Slow Policy Implementation} by the Former CPA and Coalition Forces

Although DART teams began looking into refugee and IDP return issues long before the March 2003 invasion of Iraq began, Coalition Forces and Coalition civilian authorities in charge of the issue in northern Iraq lacked sufficient preparation. Their initial actions after the war were mostly ad hoc and lacking clear, specific direction from the Coalition Authority and government in Baghdad. The resulting months of inaction put the whole return process at risk, as returnees lost faith in the new authorities and patience diminished. As late as August of 2003, several months after the end of the war, the following memo circulated in the Coalition Forces' Kirkuk Resettlement Office:

- Convey the impression to all Iraqis that we are working to address their problems and that answers will come soon.

- Investigate with the CPA as to the existence of the Iraqi Property Claims Commission and pressure them for action on this subject. 
- Establish the Kirkuk Provincial Property Claims Office, and institute a standard procedure for each claim.

- Bring in a UN representative or International agent who has experience in this matter to advise and monitor the resettlement process (i.e. Member of the commissions that resolved land issues in Bosnia or South Africa).

- Refocus all coalition efforts towards establishing the Kirkuk office and quit wasting time with individual claims that we have no power or authority to truly resolve. ${ }^{14}$

The issues raised in the memo should have been foreseen and addressed even before the fall of Saddam's government, of course. Unfortunately, Coalition Authorities did expect to have the assistance of the UNHCR, IOM, and international NGOs active on forced displacement problems, but the security situation caused the withdrawal of most of these actors and left the Coalition dealing with much more than it had bargained for.

Most importantly, however, American authorities did not wish to be the ones to make the difficult decisions regarding the future of Kirkuk, boundaries of the Kurdish Autonomous Region, and various sectarian disputes in Iraq. As a foreign occupying force they felt that they lacked the legitimacy necessary to make such important, farreaching decisions for the future of Iraq. Hence they tried to put off any substantive actions in these areas, and declared a "stay put" policy for IDPs and refugees wishing to return to south of the Kurdish Autonomous Zone. That is, while recognizing the right of all displaced persons to return, they requested that, except in the most pressing exceptional cases, returnees wait for the preparation of the areas they wish to return to, the legal determination of land ownership in contested areas, and rezoning and infrastructure work on the urban center of Kirkuk and other towns aimed at improving their capacity to absorb returns. CPA authorities asked the leadership of the KDP and PUK in particular to discourage returns until a more suitable time. In a kind of Catch-22, however, Coalition authorities also decided to avoid the creation of "pull factors" that might draw returnees in large numbers before they were ready; hence they forbade the very physical and infrastructural work they claimed they needed more time to prepare. NGOs and Kurdish authorities ready and willing to build new houses, dig wells, lay sewage pipes, and establish schools and clinics for returnees were forbidden to act until well into March 2004. Hence more than a year after the war, progress towards an integrated, comprehensive assisted-return program lagged far behind where it could have been.

The legal and politically neutral framework for compensation and the settling of property disputes between returnees and those inhabiting their original homes and lands likewise took a very long time to materialize. The Iraqi Property Claims Commission (IPCC) finally opened offices in Iraq's various governorates in March 2004 and began accepting property claims shortly thereafter. Some 19,000 claims were filed with the IPCC (the majority in Kirkuk Governorate), but as of December 2004 the Commission had yet to process a single claim. In many cases, records of land or home ownership are lacking, or complicated by the existence of several different owners over the years. The possibility of sectarian strife on the horizon likewise makes competing claims a very sensitive issue. Additionally, the IPCC's mandate only covers those who owned property when they were forcibly displaced, leaving former tenants who wish to return to their home areas with no foreseeable mechanism of assistance or compensation.

The lack of sufficient planning also led to overlapping, competing, and unclear lines of authority regarding the displaced persons dossier. Although officials of the Kurdistan Regional Government (KRG), both KDP and PUK, were the most experienced, able, and willing local authorities available to organize return programs in northern Iraq, Coalition Authorities forbade them from acting anywhere south of the "Green Line," that is, the border of the Autonomous Kurdish region since 1992. Coalition Authorities feared that allowing Kurdish officials would use any authority to act south of the Green Line to extend the de facto borders of the Kurdish region, which would spark an antagonistic reaction from Arab and Turkmen leaders in the area. Hence a multitude of actors became involved with the return issue in northern Iraq, including Coalition Forces, the Coalition Provisional Authority (CPA), the Interim Governing Council (IGC), local staff from UN offices (UNOPS, UNHCR) and the IOM, some few remaining international and local NGOs, different ministries in Baghdad (housing, displacement, and health), municipal authorities, new Iraqi police and National Guard, and, despite orders to the contrary, officials of the KDP and PUK. The resulting coordination problems and questionable lines of authority, in addition to sectarian divisions between and within some of these bodies, probably contributed to a large amount of paralysis regarding an effective return program. For example, the Iraqi central government's new Minister of Displacement and Migration, Sorya Isho Warda, offered the following observation:

At Faish Habour on the Syrian/Iraqi border all of the areas are Chaldean Christian but Arabs were moved there by force. People want to move. There is no solution for these people. Kurds asked them to move out. Kurds said they would give the Arabs US $\$ 10,000$ per house but this should be our job. We are 
discussing it with the Kurdish authorities. We want to do this the legal way, not through clashes. ${ }^{15}$

By way of contrast to the situation south of the Green Line, in the KRG area new villages have already been built and comprehensive return programs completed for thousands of Iranian Kurdish refugees who have decided to settle in Iraq rather than return to Iran. This was accomplished through effective and efficient co-operation of KRG authorities, international NGOs such as Qandil and Norwegian People's Aid, and the UNHCR.

Given the paralysis on the return issue south of the Green Line, as well as their own political calculations and strong feelings on the issue, KDP and PUK leaders seem to have ignored the Coalition's "stay put" policy. In many cases they even pressured Kurdish IDPs to return to Kirkuk and other areas south of the Kurdish Zone, either by offering them transportation south, verbally encouraging them, or even cutting off services such as electricity and water in IDP camps within the KRG area. ${ }^{16}$ By the fall of 2004, estimates of the number of returnees to the Kirkuk area alone ranged between 30,000 and 200,000, although the more likely number is around $80,000 .{ }^{17}$ Returnees tired of waiting for assistance or IPCC claims to be adjudicated have already invested in cinder blocks and begun constructing small homes throughout Kirkuk, anywhere they can find vacant land-roadsides, the International Football Stadium, abandoned lots, and public land. These new ad hoc settlements have also tapped into the electricity grid and water system of urban Kirkuk without authorization, aggravating power failures and water supply problems. Some villages destroyed by Saddam's government and not repopulated with settlers have begun being rebuilt as well.

\section{Insufficient Financial Resources to Deal with the Full Magnitude of the Displacement Problem in Iraq}

Given the magnitude of the return problem, with a total of some 800,000 IDPs in northern Iraq alone and around the same number of refugees in neighbouring countries, demand for financial resources to address the full extent of the problem will likely far outstrip supply. A comprehensive return program, of course, requires more than simply rebuilding houses and settling competing property claims-socio-economic infrastructure is needed to make returns sustainable. This is especially true when IDPs and refugees originally from rural areas have become exposed to amenities of urban living such as electricity, running water, schools, clinics, and the availability of a wider array of jobs. In the Kurdish Autonomous Zone, the large majority of IDP camps for people displaced by Saddam were established in fairly close proximity to the major urban centers of Erbil, Suleimaniya, Duhok, and Zakho, while the majority of IDPs were originally from rural areas around Kirkuk, Mosul, Makhmour, and Khanaquin. Hence, many IDPs and refugees originally from rural areas are choosing to try to settle in the urban municipalities of Kirkuk, Khanaquin, and Makhmour (because urban Mosul is predominantly Sunni Arab and a base for many insurgents, not many Kurdish, Turkmen, or Christian returnees headed there). The resulting strain on these cities makes the need for urban renewal, infrastructural improvements, and provision of services all the more pressing.

Tens of thousands of Iraqi Kurdish refugees returning from Iran, for instance, received transportation from UNOPS, a piece of land, and U.S. \$1,000 (from the KDP and PUK). Although a good start, the returnees complained that $\$ 1,000$ is hardly enough to build a house with:

Admitting that $\$ 1,000$ was likely to be too little to buy construction materials, IDP department officials in Raniya and Sulaymaniyah pointed out that the money was aimed to tide returnee families over until their situations stabilised.

"Some families can provide building materials by themselves," said Abdullah Dler in Sulaymaniyah. "Others are government employers who can get interest-free loans. Others can rely on help from their extended families," he said.

Others questioned their decision to return home. "That is true of a lot of returnees, but not of me," said Hamid Qadir Ahmed. "I should have stayed in Iran," he added. ${ }^{18}$

\section{High Expectations of Returnees vis-à-vis Continuing Lack of Opportunities and the Slow Rate of Positive Developments in the Social, Economic, and Political Situation in Iraq}

Returning IDPs, refugees, and exiles from third countries all held very high expectations following the demise of Saddam's regime. The slower-than-expected pace of improvement in Iraq has disappointed and frustrated many. The sentiment of one Kurdish returnee to Kirkuk could just as well represent that of the vast majority, including scores of IDPs interviewed by this author: "We came with the hope that the Coalition and other nations would give us the opportunity to build houses quickly. We didn't think it would take so long." 19 Because many IDPs and refugees in the area still hope that the IPCC or the new Iraqi government will compensate them for their displacement and the loss of most of their belongings, even in cases where they did not own property at the time of displacement, one can expect further disappointment soon. At the same time, however, most returnees interviewed by this author also went out of there way to insist that they were simply happy to be home, and just needed land on which to build a home and a job. ${ }^{20}$ 
The issue of returnees coming from more developed countries in Europe and North America poses a somewhat different problem, however. For example, Karim Sayid, the young University of Suleimaniya graduate who successfully migrated to Europe on his eighth attempt, told the author that nothing had changed for him in Kurdistan and he deeply regretted his decision to come back. His main complaint lay in his continuing inability to find employment. Others, such as Kamal Kochnaw, returned to the KRG region after many years in the West, and expected to be greeted as important human resources and experts by their home communities. Instead, they often discovered that they lacked the political connections and family networks needed to secure important jobs in the local economy. ${ }^{21}$ The returnees experiencing the most difficulty finding employment typically lack skills in high demand locally, however. In the two cases cited here, Mr. Sayid was a social sciences graduate with no work experience, and $\mathrm{Mr}$. Kochnaw had never finished high school, but rather ran a convenience store in Miami, Florida, for most of the twelve years since his first departure from Iraq.

Iraqi Kurdistan and northern $\operatorname{Iraq}^{22}$ in general does, however, have a great need for foreign-trained teachers, engineers, doctors, scientists, managers, and business people. KRG authorities have made public calls for such Kurdish exiles to return home and help rebuild the country. KurdSat, the satellite television station of the PUK, even publicized a new Web site where Iraqi Kurds living abroad can register their desire to return home and enrol their children in school in Suleimaniya. For the educated professionals who returned and did find important work in Iraqi Kurdistan, however, the major problem to date seems to involve the education of their children. The schools available in long-isolated regions such as the Kurdish Autonomous Zone simply can not compare to European or North American standards. The children of these returnees often also lack any experience with education in their native language, having typically been born and raised abroad. The culture shock and difficulties in adapting to local "home" cultures and norms can be significant:

I understand why my parents wanted to come back-here they are important people-but couldn't they have left me at home?' Shania Shoresh, 16, who's spent the last nine years in Earls Court, London, told IRIN. 'There's nothing for teenagers to do here, especially since a girl gets called a whore if she goes out after dark. $^{23}$

In Suleimaniya, the idea of setting up a support group for both the "returning" children and their parents has been discussed by teachers witnessing the reintegration problem. ${ }^{24}$
In October 2004, a new school in Suleimaniya, the first of its kind in Iraqi Kurdistan, was set up by Kurdistan Save the Children Fund to cater specifically to returning Kurdish families from industrialized countries. "Gasha" school in its first year only offers three hours of classes a day, but bases its teaching methods on Western models rather than the rote memorization of the Iraqi education system. The ability to provide a good education to their children may very much determine the decisions of Kurdish families about whether to make their return permanent or much briefer. One Kurdish father remarked, "I am frightened the school will not succeed. If it fails, I will have to go back to Sweden with my family." ${ }^{25}$ Given that the home community very much wants such Western exile families to return and become active in the home society, KRG authorities are considering broadening this new school initiative and possibly linking it to the International Baccalaureate system:

With thousands of families in Europe waiting to come back to Kurdistan, the ideal thing would be to change the curriculum in all schools here," said Karwan Ali, a senior field officer for KSC. "But that's impossible. Gasha is a compromise, and a blueprint for schools to convince those people back.

The difficulty with future planning is that you are extrapolating from the unknown," said Steve Harvey, a former British policeman in his second year of teaching in Sulaymaniyah. "The more successful this place is, the more people are likely to come back home." 26

Gasha school has become a kind of a haven for its Westernized Kurdish students, who feel ill at ease in a "home" society with which they have little familiarity and for whose traditional norms they lack sympathy. This may not completely solve the problem, however, as Steve Harvey explains:

...there is a real danger of this simply making them [the students] an isolated group rather than isolated individuals. When I asked my senior class, aged 14/19 today, where they saw themselves in five years time, only 3 out of 29 saw themselves as being here. If we are only educating them to keep their parents here and attract more back, is this sufficient? ${ }^{27}$

\section{Conclusion}

Although the end of Saddam's regime opened up Iraq to the return of hundreds of thousands of displaced persons, emerging political contests over the future of the new Iraq greatly complicate effective and comprehensive return programs. Coalition Forces attempted to address the returns in an impartial and legal manner, but very slow movement in implementing programs threatens to subvert their whole approach to the issue. The sheer number of actual and 


\section{Appendix 1 \\ IDP Demographics - August 2003}

Source: United States Civil-Military Operations Center Kirkuk

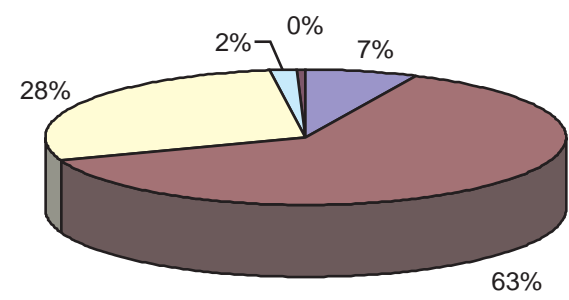

GTurkman $\square$ Kurdish $\square$ Arab $\square$ Mixed $\square$ Not Assessed

potential returnees, as well as the problem of new returnees being created due to the continuing insurgency in Iraq, will likely outstrip available resources for some time to come. At the same time, the poor security situation in the country limits the number of returns and threatens the safety of those who do return. In the end, the ultimate test of success and sustainability of return to Iraq will depend on the future of post-Saddam Iraq itself, of course. If a reasonable degree of stability is achieved, and the emerging socio-political system proves capable of peacefully accommodating the minimum aspirations of Iraq's various sectarian communities, than the largest hurdle will have been overcome.

In the meantime, the end of international sanctions and isolation of Iraq has reopened the country to the world. Irregular migrants, exiles, refugees, and diaspora communities in general are now freer than before to return to Iraq. In some cases returns will consist of simple visits, while in other cases they will be more permanent. In either case, the back-and-forth traffic may reinvigorate the Iraqi economy and society, opening them up to trade, investment, educational, professional, and cultural links to the wider world. International aid to Iraq can now move beyond simple relief programs such as UN Resolution 986 ("Oil for Food") to reconstruction and longer-term development, although the legacy of dependency that both the Oil for Food program and Saddam's authoritarian government created will take time to overcome. The extent to which return programs succeed in Iraq will also depend on the degree to which the problems discussed in this paper can be overcome. In his
Christmas 2004 speech to the troops U.S. Secretary of Defense Donald Rumsfeld cited the return of some 140,000 refugees as an Iraqi "vote of confidence in the future of the country." ${ }^{28}$ Hopefully the confidence of returnees will not be betrayed.

\section{Notes}

1. Larry Bartlett (CPA Senior Advisor to the Iraqi Ministry of Displacement and Migration), interview by the author, Baghdad, November 24, 2003. Numbers of refugees in Iran, Jordan, Saudi Arabia, and Syria from "Country Report: Iraq 2002," U.S. Committee for Refugees, <http://www.refugees.org/ world/countryrpt/mideast/iraq.htm $>$ (accessed February 1, 2004).

2. Integrated Regional Information Networks (IRIN), "Special report on internally displaced people in Iraq, Part II," Turkish Daily News, January 14, 2004:7.

3. Lisa Schlein, "UN/Iraq/Refugees," News Report, Voice of America, October 8, 2003, <http://www.globalsecurity.org/ wmd/library/news/iraq/2003/08/iraq-030810-27e56aa1.hm> (accessed November 5, 2004).

4. Bartlett.

5. Somewhere between 10,000 and 100,000 ethnic Arabs became what is referred to as "new case load" IDPs by the end of the 2003 war, due to expulsion or intimidation by returning Kurds and Turkomen or their own flight during the war. Sources disagree on the numbers, however. For an estimate of 10,000, see Luke Baker, "Returning Kurds, Turkmens threaten Iraq crisis," Reuters, January 28, 2004, <http://www.irak.be/ned/ nieuws/hotnewsJanuary04.htm $>$ (accessed February 1, 2004). Baker cites Human Rights Watch. For an estimate of 100,000, see "The Return of Kurds to Their Former Homes Has in Turn Displaced the Arabs Living in Them (2003)," The Global IDP Project, <www.idpproject.org $>$ (accessed February 1, 2004).

6. "Reversing Ethnic Cleansing in Northern Iraq," Human Rights Watch 16, no. 4 (E) (August 2004).

7. Kamal Kochnaw and Karim Sayid, interviews by the author with the assistance and translation of Karim Khallaayoun, Suleimaniya, Iraqi Kurdistan, April 2004.

8. For instance, see Jim Krane, "Kurds Flooding Back into Northern Iraq," Associated Press, September 16, 2004, Kurdistanobserver.com (accessed November 6, 2004).

9. UN News Center, "Iraq: Security Concerns Interrupt UN Refugee Agency's Return Convoys from Iran," April 6, 2004, $<$ http://www.payvand.com/news/04/apr/1041.html> (accessed November 2, 2004).

10. UN High Commissioner for Refugees, "UNHCR Return Advisory regarding Iraqi asylum seekers and refugees," October 22, 2004, <http://www.reliefweb.int/w/rwb.nsf/0/ be5d238674935d7385256f350052990b?OpenDocument> (accessed November 5, 2004).

11. UN Information Network, "Kurds Continue to Flee Cities of Sunni Triangle," October 5, 2004, <http://www.irinnews. 
org/report.asp?ReportID $=43494 \&$ SelectRegion=Iraq_Crisis \&SelectCoun try=IRAQ $>$ (accessed November 5, 2004).

12. Charles Recknagel, "Iraq: Christians Seek to Escape Pressure from Islamist Extremists, Kidnappers," Radio Free Europe/Radio Liberty, September 30, 2004, <http://truthnews.com/world/2004090244.htm $>$ (accessed November 5, 2004).

13. Stephane ' $X$,' interview by the author, Baghdad, November 26, 2003. Iraqi Christians interviewed by the author in Erbil, Dohuk, Mosul, and Baghdad all confirmed the claim that Saddam Hussein's regime uprooted Christian villages of northern Iraq, in addition to Kurdish and Turkmen ones. Whether Saddam's avowedly secular regime did so in order to increase its appeal vis-à-vis conservative Muslims in Iraqi society (the apparent logic at work when Saddam added the words "God is great" to the Iraqi flag in 1991) or for other reasons is difficult to determine, however. For more on Saddam's destruction of Iraqi Christian villages and the situation of Iraqi Christians today, see "Iraq: Christians Debate SelfAutonomy to Halt Exodus," Compass Direct News, December 22, 2006, <http://www.compassdirect.org/en/display. php? page $=$ news\&lang $=$ en \&length $=$ long\&idelement $=4711>$ (accessed January 13, 2007).

14. Undated memorandum [August 2003?], "Kirkuk Resettlement Office Proposals and Guidelines: Keys to Success," Kirkuk Resettlement Office [copy provided to the author by U.S. military personnel in Kirkuk].

15. IRIN, "IRAQ: Interview with Minister of Displacement and Migration,” December 9, 2004, <http://www.plusnews.org/ report.asp?ReportID-44592\&SelectRegion=Middle_East $>$ (accessed December 16, 2004).

16. Kurdish IDPs in the Kirkuk area, interviews by the author, February 4 and 6, 2004.

17. Thanassis Cambanis, "As Kurds Return to Oil-Rich City, a Fragile Detente,” Boston Globe, December 14, 2004, Kurdistanobserver.com, <http://home.cogeco.ca/ kurdistan5/ 15-12-04-as-kurds-return-kirkuk.htm> (accessed December $16,2004)$. My estimate of a more likely figure of around 80,000 comes from discussion held in April 2004 with Coalition Forces officials and NGO workers in Kirkuk, who estimated approximately 60,000 to 70,000 returnees were present around the Kirkuk area. A new surge of returnees arrived in August and September, just before the new school year began, which likely brought up the numbers closer to at least 80,000. Because many returnees are staying with family and friends, reliable estimates are difficult to arrive at, however.

18. IRIN, "IRAQ: Political Differences over Repatriation to North Fade Away," December 2, 2004, IRIN Web site, accessed December 16, 2004; link is no longer active, but see copy available at ReliefWeb, <http://222notes.reliefweb.int/w/rwb.nsf/0/ c8828733d74394b785256f5e006ed83b?OpenDocu ment.

19. IRIN, "IRAQ: Focus on Desperate Kirkuk IDPs," January 19, 2004, <http://iys.cici.org/humanitarian/hsr/iraq/04a/ix116. html $>$ (accessed February 1, 2004). I regularly heard the same sentiment expressed in my interviews with Kurdish and Turk- men returnees in Kirkuk during November and December 2003, and January, February, March, and April of 2004.

20. Approximately two hundred Kurdish IDPs in the Kirkuk area, interviewed by the author, between November 2003 and April 2004.

21. Kamal Kochnaw and Karim Sayid, interviewed by the author, Suleimaniya, Iraqi Kurdistan, April 2004. Mr. Kochnaw complained that "everything requires 'connections'; it's all corrupt."

22. In this paper, "Iraqi Kurdistan" refers to the Kurdish Autonomous Zone in existence since 1992, while "northern Iraq" encompasses both Kurdish areas south of the Autonomous Zone and predominantly non-Kurdish areas such as urban Mosul, Hawiija, Tal Afar, and other towns.

23. IRIN, "IRAQ: Education for European Kurds-A Tough Task," December 1, 2004, <http://iys.cidi.org/humanitarian/ hsr/iraq/04b/ix1103.html> (date accessed December 16, 2004).

24. Steve Harvey, (teacher in "Gasha" School of Kurdistan Save the Children in Suleimaniya, Iraq), e-mail communication to the author, December 5, 2004.

25. Ibid.; Steve Harvey quotes one of the parents of a student of his.

26. IRIN, "IRAQ: Education for European Kurds-A Tough Task."

27. Steve Harvey.

28. CNN, "Evening News," December 24, 2004.

David Romano is an assistant professor in the Department of International Studies at Rhodes College, Memphis, Tennessee. The author gratefully acknowledges post-doctoral research support provided by the R.B. Myers Post-Doctoral Fellowship from the Department of National Defence, Canada. 